\title{
PARENT'S PERSONAL INTERESTS IN THE FORM OF FAMILY AND EMOTIONAL RELATIONSHIP \\ WITH A CHILD AFFECTED BY PARENTING TIME INFERENCE \\ - THE PROBLEM OF MONETARY COMPENSATION DUE TO VIOLATION
}

\section{INTRODUCTION}

Despite a few aspects of the doctrine, continue to speak against the possibility of qualifying family and emotional relationship as personal interests, it may be seemed that the possibility of giving them the protection, by taking account on the facts where parenting time interference occurs intentionally, currently may not cause much controversy in Courts whereas their position on this matter is coherent. However, there is a doubt about Courts' view in the aspect of compensation of a damage caused by that kind of a behaviour through monetary compensation. That is why, the aim of this publication is to analyse relatively poor and rather publicly available judgment of Courts in the context of the issue mentioned above, as well as a dispute with an argumentation from the point of view of the ways of the compensation caused by violation of personal interests in the institution of monetary compensation as it reflected in art $448 \mathrm{CC}$.

Mgr Paulina Radomska - Doctoral Student of PhD Studies of Department of Family Law and Family Rights, Institute of Legal Sciences, Faculty of Law, Canon Law and Administration, the John Paul II Catholic University of Lublin, Al. Racławickie 14, 20-950 Lublin, Poland; e- mail: paulina. radomska1989@gmail.com; https://orcid.org/0000-0003-4073-401X

Mgr Paulina Radomska - doktorant w Katedrze Prawa Rodzinnego i Praw Rodziny, Instytut Nauk Prawnych, Wydział Prawa, Prawa Kanonicznego i Administracji, Katolicki Uniwersytet Lubelski Jana Pawła II, Al. Racławickie 14, 20-950 Lublin; e- mail: paulina.radomska1989@gmail.com; https://orcid.org/0000-0003-4073-401X 
FAMILY AND EMOTIONAL RELATIONSHIP BETWEEN A PARENT

AND A CHILD AS PERSONAL INTERESTS CONTRA PARENTING TIME INTERFERENCE AS A BEHAVIOUR THAT LEADS TO VIOLATION

On account of a lack of a proper law definition about family and emotional relationship, it should be claimed that the crucial role is done by art $446 \S 4$, added to Civil Code ( still CC) $)^{1}$ recast version form $30^{\text {th }}$ May $2008^{2}$. The aim of the institution mentioned above, is to compensate a damage caused by violation of personal interests such as family life whereas one of the reason of this damage, which is fundamental during validity of claims made by the closest family members, is exactly the aspect of permanent severing ties with the deceased. The ability of treating these relationship as an autonomic personal interests is still questionable [MichalowsKa 2017, 260-62] $]^{3}$. As it was mentioned above, in the doctrine there are a few arguments against situation where family and emotional relationship are qualified as personal interests. This was, inter alia, a subject of L. Bosek statement, where he claims that interpersonal character of family relationship as well as a lack of any connection with the inner issue cannot be assigned as personal, however, this is crucial for noting the value of personal interests [BoseK 2015, 9]. This statement is shared also by P. Księżak, who, in his deliberation about the idea of recognition of the relationship as personal interests, underlines that personal interests may not result from relationship with other person whereas possible redress by a person who suffers from violation of the other person's interests, as an exception, should be required through explicit statutory permission. As an example of such an exception, he mentioned the institution laid down in art. 446 § 4 CC [Księż̇K 2014, 312].

After all, from the point of view of this article, it should be claimed that the position of courts in this case is crucial and this might seem coherent. Courts, by accepting the possibility of qualifying family and emotional relationship between parents and children as personal interests, refer, among others, to relationship between the closest family members and the deceased person, claiming that since personal right, within the meaning of art. $23 \mathrm{CC}$, is a deceased person worship, so

\footnotetext{
${ }^{1}$ The Civil Code of 23 April 1964, Jornal of Laws of 1964, Number 16, item 93, as amended.

2 Act amending the act - The Civil Code and some other acts of 30 May 2008, Journal of Laws of 2008 , Number 166, item 731 .

${ }^{3}$ After the analysis of the judgment of the courts and the Supreme court, where beside the different ways of understanding family relationship, the tendency to mark them as autonomical personal intrests could be viewed. K. Michalowska, contrary to jurisprudence, did not find any features necessary to conider them as personal intrests [MichAŁOWSKA 2017, 279].
} 
that - a fortiori - may happen between those who live ${ }^{4}$. For the special attention in this part deserves opinion expressed in the substantiation of the judgment of Appeal Court in Warsaw from $9^{\text {th }}$ January $2013^{5}$, where an extensive fragment is devoted to the analysis of the essence of personal interests in the shape of family and emotional relationship between parents and children. In the judgment mentioned above, Appeal Court in Warsaw underlines that, as far as the subject of a family law is concerned in the field of in-house relation, the right to protect it, as an autonomic personal interests of each family members, seems to have an individual aspect whereas the value of it, along with different personal interests mentioned in art $23 \mathrm{CC}$, is inseparably linked with an individual as a subject of civil law. At the same time, the Court has indicated that every human has a right to have family relationship between the closest family members, however, the formation of personal interests might not occur from the fact of having family, but of having a real attachment. That is why, it can be severed only on condition that this relationship is experienced in a family life or on condition that a person is aware of that kind of the ties and expresses a desire of having them in the future. The above statement is expected to destroyed the arguments of the doctrine directly by regarding a lack of possibility of referring family relationship to personal one.

In further consideration, in due to specific character of cases it should be claimed, the crucial assessment of a particular claim should appear not only as a fact of limitation but also as parenting time interference as an action that undermines particular personal interests (while the assumption of being unlawful ${ }^{6}$, which is necessary to have a wrongful lawsuit, but in the case of insufficient possibility of assigning, there is not any requirement to analyse the results of violation in terms of harm or damage or its dimension ${ }^{7}$ ), however, the character of that kind of good in the form of family and emotional relationship between parents and children, according to art $113 \S 3$ of The Family and Guardianship Code ${ }^{8}$, is shown by the possibility of creating a parenting time agreement, visitation agreement, or other

\footnotetext{
4 Judgment of The Appeal Court in Lodz of 6 June 2013, act sign. I ACa 63/13, LEX number 1327565 .

5 Judgment of The Appeal Court in Warsaw of 9 January 2013, act sign. I ACa 915/12, LEX number 1289618.

${ }^{6}$ An unlawful behaviour referring to art. $24 \mathrm{CC}$ is a behaviour not relevant with legal provisions or coexistence which does not demand existing of subjective elements on the victim's side, but its evaluation made according to objective criteria, in the range of all circumstances of particular case [SZCZECHOWICZ 2012, 165].

${ }^{7}$ Judgment of The Appeal Court in Katowice of 4 November 2011, act sign. V ACa 374/11, Biul. SAKa 2012/2/24-25.

${ }^{8}$ The Family and Guardianship Code of 25 February 1964, Journal of Laws of 1964, Number 9 , item 59 , as amended.
} 
governing each parent's right to time with their child such as correspondence or other ways of having contacts at a distance. With regard to the statement mentioned above, it should not be forgotten that all the contacts should correspond to child's needs which must come first [IGNACZEWSKI 2014, 164].

Whereas, in the context of the above statement, it also should not be forgotten that parents' right to see their children and the possibility of enforcing those contacts found a protection in the art. 598 and 598 of The Code of Civil Procedure ${ }^{9}$ (still CCP) where a threat of imposing fines, court costs, or attorney's fees on the wrong doing parent is provided for The Protective Court ${ }^{10}$. However, it should be repeated for The District Court in Torun ${ }^{11}$, that those measures, according to their preventive character, are only the ways of forcing to obligate the rules of court-ordered parenting time in future. As a result, we may not find any basis to give them a character of penalty for wrongdoing performance of parents' duties in reverse as well as to give them a character of compensatory function which may be a remedy for every results mentioned above.

In accordance with this statement, it should be stated that the consequences of deliberate preventing time interference only in the matter of external sphere that is related to conscious violation of court-ordered parenting time or a parenting time agreement should be demarcated. This may result in violation of personal interests on the field of severing ties between parents and their children. However, this statement is not in opposition to the doctrine about personal interests, viewed as an objective one and protected by the law, because the protection of family and emotional relationship between a parent and a child arise from needs to protect a typical interest that is associated with the personal access to the law, coexistence, moral code, however, it is not related with an individual impression of personal protection [RADWAŃSKI 1968, 208; KOPFF 1970, 1186; IDEM 1982, 39] ${ }^{12}$.

9 The Code of Civil Procedure of 17 November 1964, Journal of Laws of 1964, Number 43, item 296, as amended.

${ }^{10}$ These provisions were added to The Civil Code pursuant to the provisions of the Act amending the act - The Code Civil Procedure, Jorunal of Laws of 2011, Number 144, item 854. According to the view of Minister of Justice K. Kwiatkowski, where the project of the new regulation was made, and where the publication of K. Krupa-Lipińska was appointed after him, it should be claimed that those regulations shall be treated as effective way of a stimulus to obligate the rules by the parents, who interfer the contacts because of a bad attitude caused by anger or hate [KRUPA-LIPIŃSKA 2016, 16].

${ }^{11}$ Decision of District Court in Torun of 10 August 2012, act sign. VIII Cz 392/12, LEX number 1714407.

12 Vide: Judgment of The Supreme Court of 28 May 1971, act sign. III PZP 33/70, OSNCP 1972, number 11, item 188 [SокоєоWSKI 2012, 128-29]. 


\section{COMPENSATION OF NONMATERIAL HARM OR PUNISHMENT FOR PARENTING TIME INTERFERENCE?}

A starting point for further consideration about the nature of the case and the function of the institution of monetary compensation should be the judgment of The District Court in Gdansk from the $9^{\text {th }}$ December 2014 (not yet reported) and announced on appeal of the judgment of The Appeal Court in Gdansk from the $15^{\text {th }}$ July $2015^{13}$, where the circumstances, in terms of personal interests, were justified.

On the base of established facts which lies at the heart of this publication, The District Court in Gdansk concluded that the defendant who limited not only the contacts between the plaintiff and the child but also who interfered into contacts via telephone or other forms of electronic communication, consequently leads to permanently severing ties which is an act of violation of personal interests. This resulted in emotional harm, pain and suffer. However, The Court has refused to grant any monetary compensation for this nonmaterial harm by referring to its optional character. At the same time, arguing that the nature of the case continues to be still a family dispute and ordering the defendant monetary compensation might encourage the children to feel that the plaintiff is a person who oppresses their mother. What is more, The Court demanded the return of alimony in reverse explaining that this has turned to be a measure of the amount of a claim. In the Court's opinion, giving the civil law protection to personal interests in the situation where a family dispute has occurred, would only cause an abuse of the right to a trial as well as would be against coexistence. The Court indicates that the defendant has started the lawsuit about monetary compensation in the helpless of the authorities as well as of her own in the aspect of parenting time agreement. The Court has claimed also that monetary compensation should not be treated as a property issue because non effective action of the authorities does not bring the law protection to it as it follows from the regulatory provisions on personal interests. What is more, The Court has stated also that the aim of the institution is to implement the compensatory function as well as to satisfy the victim. However, according to the financial situation of the defendant, monetary compensation will not reduce the pain suffered from contact interference whereas his admission of guilty is unintentional because personal interests in the form of emotional relationship between family members are a combination of attachment between those

${ }^{13}$ Wyrok Sądu Apelacyjnego w Gdańsku z dnia 15 lipca 2015 roku, sygn. akt I ACa 202/15, LEX nr 1770654, [Judgment of The Appeal Court in Gdansk of 15 July 2015, act sign. I ACa 202/15, LEX number 1770654]. 
people. As a result, children do not want to have any contacts because of illegal and intentional acting of the defendant.

The Appeal Court in Gdansk claimed that The Court of First Instance has committed an infringement of the substantive law under the art 448 included art $24 \S 1$ and art $23 \mathrm{CC}$, consisting in misinterpretation and misapplication of the art, and has come to the different conclusion. Firstly, The Court reffered to the aim of the institution of monetary compensation under art $448 \mathrm{CC}$, underlined that the main function of it, is the compensation which has a fundamental role. At the same time, the court has denied the interpretation of the court of the first instance according to which it can not have repressive or preventive role which reffered to the circumstances in the form of psychological and moral aspects of the victim, the circumstances considered by the court as a negative one as well as the intensity and the degree of a harm. The Court indicated that this function can not support compensation, but only to 'enrich' it in general. Whereas any refusal of compensation for the reason that is not related to compensatory function, but only to prevenetive or repressive one. This may only happen on condition that there is not much harm done by the person and in this case such a thing never happened. The appeal Court in Gdansk did not accept the argumentation of The Court of First Instance within the range where it has refused a civil law protection of personal interests due to family dispute, explaining that against its statement argues the art $23 \mathrm{CC}$, according to which personal interests of human being are protected by civil law, independently of protection under other regulations. The Regulations of Family code and Caring are not lex specialis towards The Regulation of Civil code, devoted to protection of personal interests and therefore they can be applied in parrarell. What is more, it should be stressed that because of the constant lack of contacts with children the compensation should be made but only if it is caused by the behaviour or action under art $24 \S 1 \mathrm{CC}$ included in art $448 \mathrm{CC}$. where it is shown that the compensation can be made due to violation of personal interests and the existing of it is not as important as the amount of compensation which depends on the amount of violation. However, in the other explanation, The court has indicated any statements of the court of first instance, referring to a hypothetical facts which did not exist at the trial close and did not have any reflection on evidence.

In the context of the analysis mentioned above, to the fore comes a two different views of The Courts in the field of the interpretation of the compensatory function. The argumentation of The District Court in Gdansk strictly denied the possibility of giving the institution of monetary compensation for a damage a penalty function, however, this may raise concerns about it, that is why we shall accede to the statement presented by The Appeal Court in Gdansk, especially be- 
cause of Its view on a repressive and preventive function of compensation which may have also a reflection on the doctrine ${ }^{14}$ as well as judgment of The Supreme Court ${ }^{15}$ under which the institution of the compensation laid down in art $448 \mathrm{CC}$ that appears in the place of claiming of monetary compensation from a suspect towards Polski Czerwony Krzyż, still has some repressive elements even though they are not equal towards a compensatory function. The remaining aspects associated with a family dispute, which is as it seem to be in that kind of a case essential, as well as with a financial situation of a victim and with a hypothetical influence on compensation for the parenting time interference belongs to stricte evaluating statements that should be claimed after the analysis of the case and evidence $^{16}$. That is why it is not appropriate not to agree with the Appeal Court in Gdansk under which violation is caused by family dispute and the possibility of enforcing contacts with the children within the regulation of Family code and Care where the civil law protection of personal interests is not excluded. However, it is difficult to consider it as meaningless for this case. It should be underlined that the cases- that reflect the facts- consist of different elements which depends on family dispute ${ }^{17}$ as well as an acting that firstly may seem to be unimportant,

${ }^{14}$ The article of A. Szpunar should be presented as an example. In this article, such a statement can be found: "in polish law the compensatory function of a liability of a damage shall come at first" [SZPunAR 2003, 17]. That is why, it has to be considered as major function, closely realted to responsibility of compensation. However, the other function has a helpful or complementary role. M. Wilda, discussing the institution of monetary compensation for a damage suffered by a damge to health or to body, claims that compensation based on art $448 \mathrm{cc}$ has a compensatory and repressive function in much further context on contrary to compensation based on art $445 \S 1$ CC However, according to the institution mentioned above - on the contrary to the other one- the experience aims to overcome the consequences of a damage such as satisfaction that comes from the reaction of legal order of the incident or from causing a suffer to a suspect [WILDA 2011, 4], which confirms the statement mentioned above. For that kind of compensation stands the authors as Z. Radwanski and J. Panowicz-Lipska [RAdwaŃski 1968, 164; Panowicz-Lipska 1975, 114].

${ }^{15}$ Compare: Resolution of The Supreme Court of 9 September 2008, act sign. III CZP 31/08, OSNC 2009, number 3, item 36, as well as Judgment of The Supreme Court of 8 August 2017, act sign. I PK 206/16, LEX number 2333062.

${ }^{16}$ The statement mentioned above, has its reflection in the rule of casual assessment of evidence related to ordering the evaluation expressed in trustworthiness aspect, in the field of comprehensive consideration of the case, consisting of not only means of evidence, but also art $228 \S 1 \mathrm{CCP}$, facts known by the court from office (art. $228 \S 2$ CCP), conferred facts (art. $229 \mathrm{CCP}$ ), undeniable facts (art. $230 \mathrm{CCP}$ ) and law assuption (art. $234 \mathrm{CCP}$ ) as well as finalising the circumstanes of marking the evidance which are crucial for evaluating its capacity and reliability [PIETRZYKOWSKI 2014, 530].

${ }^{17}$ The context of evaluating a family dispute should be considred in three fundamental circumstanes as they are viewed by P. Telusiewicz, that is, the fact of constant family dispute (as it was stated above between former spouses, but it should be claimed that this kind of a dispute may start during a marriage that is why, according to the author, it may be considered as a family one), the crucial reason of a dispute where can possibly occur - yet do not have to - the case reffering to the 
however, at the end it may have a great impact on the case in general as well as on the final outcome as it may be discuss further below.

\section{„THE RELEVANT AMOUNT” UNDER MONETARY COMPENSATION FOR NONMATERIAL DAMAGE - SUBJECTIVE AND OBJECTIVE CRITERIA DETERMINING THE AMOUNT}

Ultimately, The Appeal Court in Gdansk states that the claim of the plaintiff, in principle, is justified. However, at this point it should be indicated that a court may refuse to order monetary compensation only in the situation when it states, by objective criteria, that it is not necessary to compensate a moral damage through monetary compensation whereas its leeway in this aspect is not considered whether to order monetary compensation or not, but is used to evaluate if monetary compensation in a particular situation is reasonable or if there is any other possibility to compensate a damage in the application of certain nonmaterial security measures. The Court has ordered the plaintiff to pay compensation for the nonmaterial damage suffered by the defendant that is compatible with objective criteria, amounting $5000,00 \mathrm{zl}$. At the same time, claiming that the amount of the compensation depends on a kind of a damage, a scope of it as well as its intensity because these criteria are associated with a compensatory function whereas the amount mentioned above is associated with a compensatory value that compensate nonmaterial damage of the defendant. However, the claim of compensation, equal to the sum of alimony that has been paid, is considered as unreasonable and falls outside subjective as well as objective criteria.

It should be claimed that the argumentation of The Appeal Court in Gdansk, mentioned above, is rather laconic one- it has confined itself only to cite the criteria of monetary compensation based on art $448 \mathrm{CC}$, common to all kinds of violation of personal interests, excluding the elements which are crucial for explanation of personal interests in the form of emotional and family relationship with a child, resulting not only from its specification but also from specific behaviour that leads to violation. That is why, it is necessary to cite the statement of The District Court in Olsztyn, justified in the judgment from $27^{\text {th }}$ June $2017^{18}$, which was passed on the ground of different facts, where the parenting time interference occurred in

family as a whole or to the particular family members, what is more, much longer duration of this dispute [TelusiewiCz 2013, 182-83].

${ }^{18}$ Judgment of The District Court in Olsztyn of 27 July 2017, act sign. IX Ca 252/17, Portal of judgments of The District Court in Olsztyn, http://orzeczenia.olsztyn.so.gov.pl [access: 5.05.2019]. 
a way that the plaintiff prevented a child from seeing a father. As a consequence, parental authority has been changed towards her, however, the conclusion was equal in the field of the basis of violation of personal interests in the form of family and emotional relationship. The District Court in Olsztyn focused its attention on the fact that a damage and amount of the compensation belongs to subjective criteria, difficult to evaluate even if an objective circumstances are taking into account. The relevant amount should be specified by the plaintiff in the wording of a lawsuit, that might be a compensation of a damage suffered by him. However, this may be somehow a subjective aspect used to determine the scope of this damage because the individual view of a damage and compensation should be crucial for evaluating the amount of monetary compensation in the situation where there are not any other objective norms. At the same time, the court has indicated objective grounds, used to evaluate the scope of a damage to where a kind of violation of personal interests belongs, claiming that the defendant, by her behaviour, violated the plaintiff's personal interests in the form of family relationship with a child whereas the circumstances, that had an impact on a damage suffered by him, were related to duration of loss of contacts with a child as well as to the fact that a child has been at the age where it is crucial to have right family relationship.

According to the statements mentioned above, in the field of reasonable compensation as well as its amount, the argumentation should be presented in explanation of the judgment of The District Court in Lublin from $31^{\text {st }}$ July $2017^{19}$. The District Court in Lublin claimed that the defendant's behaviour, consisting in depriving and prevention of the contacts between the plaintiff and a child, was unlawful and ,the same as The District Court in Gdansk, it has denied to order compensation based on art $448 \mathrm{CC}$, by referring to two independent of each other and in his reviewcomplementary-reasons. Firstly, it refers to the circumstances of not facing by the plaintiff, the obligation of having contacts that leads to temporary severing ties with a child. As a result, this may cause changes of his personality that may be considered as a damage and a reason for claiming compensation. Secondly, The District Court in Lublin invoked his statement on art 5 CC, justifying it on account of a family dispute, which leads the defendant to concern that the plaintiff wants to deprive her from contacts with a child by taking him and refusing to return the child in violation of a court order. What is more, the plaintiff's motivation of his claiming was a financial competition with the defendant which presents inappropriate plaintiff's attitude toward a child. At the same time, The Court did not find any basis to approve the plaintiff's claim about the defendant's violation of

19 Judgment of The District Court in Lublin of 31 July 2017, act sign. I C 398/16, Portal of judgments of The District Court in Lublin, http://orzeczenia.lublin.so.gov.pl [access: 5.05.2019]. 
his personal interests in the form of family relationship with a child, underlining that during the legal process the defendant has stopped the actions that may strive to prevent from implementation of the contacts.

The provisions of The Civil Code do not have any grounds, that should be taken into consideration by courts while determines the amount of monetary compensation for a damage suffered, that is why, according to facts of difficulties in indication of equal, repetitive criteria of damage evaluation, however, the crucial role of setting the amount is judicature [WAŁACHOWSKA 2007, 126]. Quite apart from this consideration, on the basis of Courts' reflection, (per analogiam due to subjective and objective aspects of violation of personal interests) subjective and objective criteria of setting the amount of monetary compensation for a harm suffered can be distinguished and it should be claimed that, every feeling of a person who demands protection based on regulation mentioned above, can be classified to subjective criteria. However, the elements, in the range of an average social assessment, are expressed by accessing to the law, the rules of coexistence and moral principles [cf. SoKOŁOWSKi 2012, 127-29; RADWAŃSKi 1968; KoPfF 1970; IDEM 1982, 39]. One could agree with The District Court in Olsztyn that due to the lack of objective forms of a damage evaluation, a damage itself and its relaxation should be individually regarded, which is crucial for evaluating the amount of compensation. In this situation, it must not lose sight of art $448 \mathrm{CC}$ where a damage is compensated as a nonmaterial damage caused by violation of personal interests whereby psychological suffer of a victim (subjective criteria). And therefore, the basic meaning of setting the amount of compensation should be made through the circumstances and the scope of a damage. During the ways of defining its scope, objective criteria, such as a kind of violation of personal interests, the scope, intensity and duration of violation, results of violation, as well as all the guilt of a suspect, should be considered ${ }^{20}$. That is why, it should be claimed that the criteria mentioned above complement each other, what makes the amount of monetary compensation, only due to subjective and objective criteria, impossible to set.

Due to the specific nature of personal interests and violation mentioned above, in many situation of severing ties in the shape of family and emotional relationship, there should be some kind of a searching for analogy in the field of violation criteria and its scope, the circumstances of severing family ties with a child

${ }^{20}$ Vide: Judgment of The Supreme Court of 9 January, act sign. IV CR 510/77, OSN 1978, number 11, item 2010; Judgment of The Supreme Court of 19 August 1980, act sign. IV CR 283/80, OSN 1981, number 5, item 81; Judgment of Supreme Court of 1 April 2004, act sign. II CK 131/03, LEX number 327923; Judgment of The Supreme Court of 20 April 2006, act sign. II CK 131/03, LEX number 198509. 
or with other family member dues to his death ${ }^{21}$. Despite the fact of the obvious permanent results of a behaviour that leads to violation of personal interests of a family of the deceased, the statement should not be considered as too daring because its aim is not to level the amount of a damage suffered from violation. Therefore, it should be noticed that, in the cases of violation due to the death of the closest family member, the amount of a damage is set by an expert knowledge after consulting it, in the course of proceedings, with a psychological expert as well as with a forensic expert in the range of psychiatry, who set the percentage of an amount of a damage to psychological health of a victim due to the table in annex of Regulation of The Minister of Labour and Social Policy of 18 December 2012 about detailed rules of judgment about permanent or long-lasting damage to health as well as the procedure of a one-time compensation payment ${ }^{22}$. According to the judgment of the courts in this range, the statements mentioned above should not have any impact on setting the amount of compensation. However, it should be indicated that the element such as a damage to psychological and emotional health cannot be considered as dominant, yet the issues related to this might not be omitted but might be treated as a helpful one. The basis of the statement, related to reasonable claiming reflected in art $446 \S 4$ or art $448 \mathrm{CC}$, should be considered as dominant and foreground in the field of severing family ties ${ }^{23}$.

Referring above statements to the subject of this article as well as to the argumentation of the judgment of The District court in Lublin, it might be said that a victim's failure to proper presentation of the results of temporary severing ties with a child as psychological changes that may be reflected in a damage to health, however, this might not be enough basis to reject his claim about compensation, especially by claiming that temporary serving ties, in the form of family relationship between a victim and his child, caused a kind of psychological discomfort. Therefore, the most important aspects in this case should be devoted to severing ties in the form of family and emotional relationship with a child, as they were mentioned in the judgment of the Direct Court in Olsztyn, that is, permanent loss of contacts with a child, and the age of a child that has an impact on his relationship, what is more, its duration as well as reversibility of violation consisting in the possibility (or its loss) of forming family and emotional relationship again. It

\footnotetext{
${ }^{21}$ The subjective connotation corresponds to K. Michałowska statement in the range of monetary compensation for a damage suffered to the closest family members of the deceased, based on art. 446 $\S 4 \mathrm{CC}$ in the range of creating the meaning of family and emotional relationship [MichatowsKA 2017, 260].

22 Journal of Laws of 2002, Number 234, item 1974, as amended.

${ }^{23}$ Judgment of The Appeal Court in Lublin of 16 October 2013, act sign. I ACa 391/13, Portal of judgments of The Appeal Court in Lublin, http://orzeczenia.lublin.sa.gov.pl [access: 7.05.2019].
} 
shall be considered that the fact of not indicating, in a proper way by the plaintiff, a damage to his psychological health, results in reducing the amount of monetary compensation.

\section{FINAL REMARKS}

Although, the lack of publicly available judgment, in the field of the subject discussed, may have a highly disruptive effect. On this basis, the analysis confirms that the lack of coherent line in the judgment may cause the situation in which, in fact, there are divergent argumentation. The statement mentioned above, may be presented in the view of different criteria of evaluating the reasons of monetary compensation for a damage caused by intentional parenting time interference or disrupting contacts, also a lack of distinguishing aspects of personal interests in the form of family and emotional relationship between a parent and a child as well as a behaviour that leads to violation.

What is more, the exact Courts' tendency to reject the possibility of compensation of a damage associated with a wrong demarcating of a civil law protection of personal interests from the possibility of claiming the contacts with a child based on other regulations, as well as drawing the conclusion from the fact of having a family dispute between parties, without the exact verification of it, its coursing and its intensity - as it was mentioned before, it may seem that the appearance of a family dispute, in the field of such cases, turns to be crucial part of it, that is why, the appearance of the circumstances cannot result in rejecting the claim of compensation. On the contrary, it shall be concluded that the intentional behaviour that leads to parenting time interference by impeding contacts with a child during a family dispute, cannot be considered as unlawful - however, the plaintiff as well as the defendant could explain their behaviour as necessary for taking care of child's personal interests no matter what the real reasons were.

Finally, due to the universality of a practice consisting in parenting time interference and a line in the judgment, as it was practised by the Appeal Court in Gdansk, more and more cases devoted to this shall be expected ${ }^{24}$. That is why, the subject of this article should be presented by the statement of The Supreme Court, which may result in controlling the chaos in the field of judgment that is made due to compensation, related to the institution of monetary compensation,

${ }^{24}$ This view is shared by K. Krupa-Lipińska, whose publication was also devoted to the subject mentioned above [KRUPA-LIPIŃSKA 2016, 26]. 
after a damage suffered from violation of personal interests which are caused by deprivation of the contacts.

\section{REFERENCES}

BoseK, Leszek. 2015. „W sprawie kwalifikacji więzi rodzinnej jako dobra osobistego (uwagi krytyczne na tle aktualnego orzecznictwa Sądu Najwyższego).” Forum Prawnicze 29 (3):3-19.

IGNACZEWSKI, Jacek. 2014. „Sprawy o kontakty z dzieckiem i o ich wykonanie.” W Komentarz do spraw rodzinnych, red. Jacek Ignaczewski, 68-165. Warszawa: LexisNexis.

KopfF, Andrzej. 1970. „Glosa do wyroku Sądu Najwyższego z dnia 19 września 1968 roku, sygn. akt II CR 292/68." Nowe Prawo 7-8:1185.

KopFF, Andrzej. 1982. „Ochrona sfery życia prywatnego w świetle doktryny i orzecznictwa.” Zeszyty Naukowe Uniwersytetu Jagiellońskiego. Prace Prawnicze 100:35.

KRUPA-LIPIŃSKA, Katarzyna. 2016. „Naruszenie dobra osobistego w postaci więzi rodzinnej poprzez utrudnianie kontaktów z dzieckiem." W Dobro dziecka w ujęciu interdyscyplinarnym, red. Katarzyna Krupa-Lipińska, 7-26. Toruń: Wydział Prawa i Administracji Uniwersytetu Mikołaja Kopernika w Toruniu.

KsIĘŻAK, Paweł. 2014. „Komentarz do art. 23-24.” W Kodeks cywilny. Komentarz. Część ogólna, red. Paweł Księżak, i Małgorzata Pyziak-Szafnicka, 267-352. Warszawa: Wolters Kluwer Polska.

MichaıOwsKa, Kinga. 2017. Niemajątkowe wartości życia rodzinnego w polskim prawie cywilnym. Warszawa: C.H. Beck.

PANOwicz-LipsKa, Janina. 1975. Majątkowa ochrona dóbr osobistych. Warszawa: Wydawnictwo Prawnicze.

PieTRZYKOWSKi, Henryk. 2014. Metodyka pracy sędziego w sprawach cywilnych. Warszawa: LexisNexis.

RADWAŃSKI, Zbigniew. 1968. „Glosa do postanowienia Sądu Najwyższego z dnia 18 października 1967 roku, sygn. II CZ 94/67.” Orzecznictwo Sądów Polskich i Komisji Arbitrażowych 208.

RADWAŃSKI, Zbigniew. 1968. „Roszczenie o zapłatę odpowiedniej sumy pieniężnej na rzecz Polskiego Czerwonego Krzyża w razie umyślnego naruszenia dóbr osobistych.” Ruch Prawniczy Ekonomiczny i Socjologiczny 3:159-70.

SoKoŁowski, Tomasz. 2012. „Komentarz do art. 24 k.c.” W Kodeks cywilny. Komentarz. Tom I. Część ogólna, red. Andrzej Kidyba, 127-37. Warszawa: Wolters Kluwer Polska.

Szczechowicz, Jarosław. 2012. „Prawne aspekty ochrony dóbr osobistych.” Media - Kultura Komunikacja Społeczna 8:164-77.

SzPunAR, Adam. 2003. „Uwagi o funkcjach odpowiedzialności odszkodowawczej.” Państwo i Prawo $1: 17-26$

Telusiewicz, Piotr. 2013. Stużebna rola zwrotu „rodzinny” w przepisach prawa polskiego. Lublin: Wydawnictwo KUL.

WalachowsKa, Monika. 2007. Zadośćuczynienie pieniężne za doznana krzywdę. Toruń: Dom Organizatora. 


\title{
PARENT'S PERSONAL INTERESTS IN THE FORM OF FAMILY AND EMOTIONAL RELATIONSHIP WITH A CHILD AFFECTED BY PARENTING TIME INFERENCE - THE PROBLEM OF MONETARY COMPENSATION DUE TO VIOLATION
}

\author{
Sum mary
}

The possibility of qualifying family and emotional relationship as personal interests and giving them the protection by taking account on the facts where parenting time interference occurs intentionally, currently may not cause much controversy in Courts. However, there is a doubt about Courts' view in the aspect of compensation of a damage caused by that kind of a behaviour through monetary compensation. That is why, the aim of this publication is to analyse relatively poor and rather publicly available judgment of Courts in the context of the issue mentioned above, as well as a dispute with an argumentation from the point of view of the mentioned above way of the compensation of damage. The content of the publication, based on literature and judicature of Courts and The Supreme Court, contains a presentation of a range of the conception of family and emotional relationship between a parent and a child as personal interests, a demarcation of the consequences of deliberate preventing time interference only in the matter of external sphere and its ravages in the matter of inner psychic sphere, analysis of the monetary compensation functions in reference to presented judgements as well as a discussion on subjective and objective criteria determining "the relevant amount" under monetary compensation for nonmaterial damage. Finally, analysis of the judgements allowed to draw interesting conclusions, among which came to the fore ascertainment, that the lack of coherent line in the judgment may cause the situation in which, in fact, there are divergent argumentation.

Key words: family dispute; severing ties/attachment; subjective and objective criteria; compensatory function; repressive and preventive function

\section{DOBRO OSOBISTE RODZICA W POSTACI WIĘZI RODZINNYCH I EMOCJONALNYCH Z DZIECKIEM NARUSZONE WSKUTEK UTRUDNIANIA KONTAKTÓW - PROBLEM KOMPENSACJI KRZYWDY DOZNANEJ W ZWIĄZKU Z JEGO NARUSZENIEM W DRODZE ZADOŚĆUCZYNIENIA PIENIĘŻNEGO}

\section{Streszczenie}

Możliwość kwalifikacji więzi rodzinnych i emocjonalnych jako dobra osobistego oraz przyznania temu dobru ochrony na tle stanów faktycznych, w których dochodzi do celowego ograniczania lub też uniemożliwiania jednemu z rodziców kontaktów z dzieckiem, obecnie nie wywołuje już większych kontrowersji wśród sądowych powszechnych. Wątpliwości budzi natomiast ich zapatrywanie w aspekcie możliwości kompensacji krzywdy będącej wynikiem takiego zachowania w drodze zadośćuczynienia pieniężnego. Dlatego też jako cel niniejszej publikacji, obrano analizę stosunkowo ubogiego, ogólnodostępnego orzecznictwa sądów powszechnych w kontekście powyższego zagadnienia, jak również polemikę z zawartą $\mathrm{w}$ nich argumentacją, z perspektywy wymienionego wyżej sposobu kompensacji krzywdy. W jej treści, w oparciu o literaturę oraz ogólnodostępne orzecznictwo sądów powszechnych i Sądu Najwyższego przedstawiono zakres pojęciowy dobra osobistego rodzica w postaci więzi rodzinnych i emocjonalnych łączących go z dzieckiem oraz odgraniczono konsekwencje jego naruszenia w zakresie odnoszącym się do sfery zewnętrznej od jego skutków w ramach wewnętrznej sfery psychicznej, dokonano analizy funkcji instytucji zadośćuczynienia pieniężnego za doznaną krzywdę w nawiązaniu do treści zaprezentowanych judykatów, jak również 
omówiono subiektywne i obiektywne kryteria ustalenia wysokości „odpowiedniej sumy” tytułem zadośćuczynienia pieniężnego za doznaną krzywdę. Końcowo analiza orzecznictwa pozwoliła na sformułowanie interesujących wniosków, wśród których na pierwszy plan wysuwa się stwierdzenie, iż brak jednolitej linii orzeczniczej prowadzi do sytuacji, w której na gruncie tożsamych lub co najmniej zbliżonych stanów faktycznych zapadają rozstrzygnięcia oparte na skrajnie rozbieżnej argumentacji.

Słowa kluczowe: konflikt rodzinny; zerwanie więzi; kryteria subiektywne i obiektywne; funkcja kompensacyjna; funkcja represyjno-prewencyjna 